\title{
Comparing wireless networks for applying digital textbook
}

\author{
Jae Sung Song • Seong Jin Kim • Gi Seob Byun • \\ Ju Ho Song • Bong Gyou Lee
}

Published online: 16 January 2014

(c) The Author(s) 2014. This article is published with open access at Springerlink.com

\begin{abstract}
The digital textbook is a suitable medium for the provision of customized education that fits each individual's needs, and for the ongoing changes in educational needs such as a self-directed learning ability. This paper reviews selection criteria for the wireless network to be applied to digital textbook. At present, it is believed that wireless LAN was selected for the digital textbook in Korea because it provides a better data rate and greater cost-effectiveness than the other wireless network technologies. However, wireless LAN is inferior to the other technologies in terms of mobility and security. The future wireless network for digital textbook will be guaranteed that it can meet the requirements of data rate and mobility. Therefore, for the digital textbook with characteristics of public welfare, it would be worthwhile to consider allowing the installation and operation of the internal mobile WiMAX network.
\end{abstract}

Keywords Wireless communication technology · u-Learning · Digital textbook · Mobile WiMAX

\author{
J.S. Song ( $\varangle)$ · S.J. Kim · G.S. Byun · J.H. Song · B.G. Lee \\ Graduate School of Information, Yonsei University, \\ 134 Shinchondong, Seoul 120-749, Korea \\ e-mail: jssong@kcc.go.kr \\ S.J. Kim \\ e-mail: saintkim@gmail.com \\ G.S. Byun \\ e-mail: tgbgs@yonsei.ac.kr \\ J.H. Song \\ e-mail: itrd@yonsei.ac.kr \\ B.G. Lee \\ e-mail: bglee@yonsei.ac.kr
}

\section{Introduction}

Conventional textbooks, which are still commonly used, are preferred mainly from the perspective of reading physiology, including their high portability, ease of use, excellent readability, and moderate price. For the traditional purpose of education, namely the acquisition and transfer of knowledge, traditional textbooks fulfill their expected roles.

However, despite their many strengths, it is becoming difficult for conventional textbooks to cope with the requirement of adding and transferring new information, because the speed of knowledge accommodation is increasing due to the proliferation of new media, which is represented by rapid technical development and the Internet, and the lifecycle of knowledge is being diminished due to the rapidly changing pace of the social environment [19].

Korea has been promoting methods of utilizing digital textbooks based on its advanced IT infrastructure, in order to overcome the limitations of traditional textbooks. The Ministry of Education, Science and Technology (MEST) and the Korea Education and Research Information Service (KERIS) established a method of promoting the commercialization of digital textbooks in 2007, and have been developing and distributing digital textbooks since then in line with the future education paradigm. The MEST is investing about 51.7 million USD $^{1}$ in total from 2007 to 2011 to implement the project [19]. The MEST also introduced digital textbooks to 112 primary schools as an experiment (as of 2009), and will gradually expand the scope of their application to middle and high schools. On the other hand, wireless technology and applications have seen remarkable

${ }^{1}$ Currency 1 USD = 1,276 won, 2009 annual average exchange rates [29]. 
development in various areas over recent decades. Ubiquitous access is now feasible, enabling users to obtain the desired information at any time and place [32]. Thanks to these technical developments, the implementation of a learneroriented u-Learning system is making good progress, in an education paradigm that is entirely different from existing paradigms [18].

The ubiquitous network is as an important factor in the creation of a digital textbook environment that can support the u-Learning environment, which will enable students to access study materials at any time and place, besides the simple digitalization of conventional textbooks. Thus, it is deemed essential that the wireless network technology currently in use should offer sufficient bandwidth and connection speed at a moderate price, so that quality similar to that of regular book reading can be provided, in order to expand and commercialize the digital textbook service based on the ubiquitous network.

This study reviews the appropriate wireless network for digital textbooks, using Korean cases. The study is based on recognition of the fact that the characteristics and quality of the digital textbook itself, as well as the capacity and performance of terminals and wireless networks that use the digital textbook, will determine whether the digital textbook business will be successful or not. In practice, the digital textbook project in Singapore encountered difficulty in the early stage due to the slow rate of data provision. Taking the case of Singapore into account, it can be said that this study on the role of the wireless network in supporting the use of digital textbooks is particularly meaningful.

Section 2 describes the concept and cases of utilization of digital textbooks, while Sect. 3 introduces overall digital textbook projects in Korea. Based on the details given in Sects. 2 and 3, Sect. 4 discusses the criteria for wireless network selection. Section 5 proposes the policy implications for the digital textbook project by describing the limitations of this study and outlining the areas in which future study will be required.

\section{Concept and utilization cases of digital textbooks}

\subsection{Concept of the digital textbook}

The term "digital textbook" was used first by the KERIS as shown in Fig. 1 in 2007; prior to that, the term "electronic textbook" was used [5]. Some define the digital textbook as a comprehensive study textbook that adds the content of various reference books to the existing printed textbook, as well as incorporating various simulations, multimedia data, and the functions of a database (assessment questions), and various management programs. Others define it as "a textbook that maximizes the learning effect and convenience by converting book-type textbooks into the electronic format to retain the strengths of the traditional book format, and by adding various multimedia study functions (e.g., animation, 3D) and other functions (e.g., search, navigation) [1]. With the appearance of digital textbooks, learners can access the latest multimedia data-such as moving pictures, animation, and virtual reality — besides existing study materials, and use them for study in real time.

Earlier, relevant studies include a comparative study on student's learning capability compared with existing textbooks [26], and adaptability [30], as well as a study on the intelligent education system, using the web [25] and terminals suited to digital textbook study [17, 18]. In addition, there have been a number of studies on the wireless network-for instance, interaction among heterogeneous networks like WLAN and WiMAX [31], but virtually no studies have been conducted to determine which wireless network is appropriate for the digital textbook. In an attempt to find a wireless network suitable for the digital textbook, Song, Jae-seong et al. [28] conducted a comparative study of the wireless LAN, HSDPA, and mobile WiMAX network from the perspectives of data rate, and development and operation expenses. However, their comparison criteria were arbitrary and somewhat limited in scope. Based on the information system auditing criteria, this paper expands the study result of Song, Jae-seong et al. [28] to various aspects—-such as security, availability, scalability, and ease of maintenance-in order to review the issue of selecting a proper wireless network for the digital textbook from a comprehensive point of view.

\subsection{Examples of use}

NUVO Media in the U.S. released the Rocket e-Book-the world's first dedicated e-Book terminal in October 1998. A simple e-Book reader, it enables the user to download eBook content by connecting via the PC serial port, and to exchange the content with other users using the Rocket Library (www.rocket-library.com).

GoReader, founded in the spring of 2000, announced an electronic textbook (under the same name) for exclusive use with the terminal, concluded an agreement with several publishers regarding book digitalization, and conducted experimental research at the University of Chicago, Wake West University, and Highland Park High School. Besides the simple reading function, the terminal included a number of other functions that are also possible with traditional books, such as highlighting pen, pencil, and Post-it note. The functions provided by the terminal were almost the same as those offered by the current digital textbook. However, the terminal failed in the market due to its high price and concentration on dispersion by simple sales [19]. 
Fig. 1 Concept of the digital textbook [19]

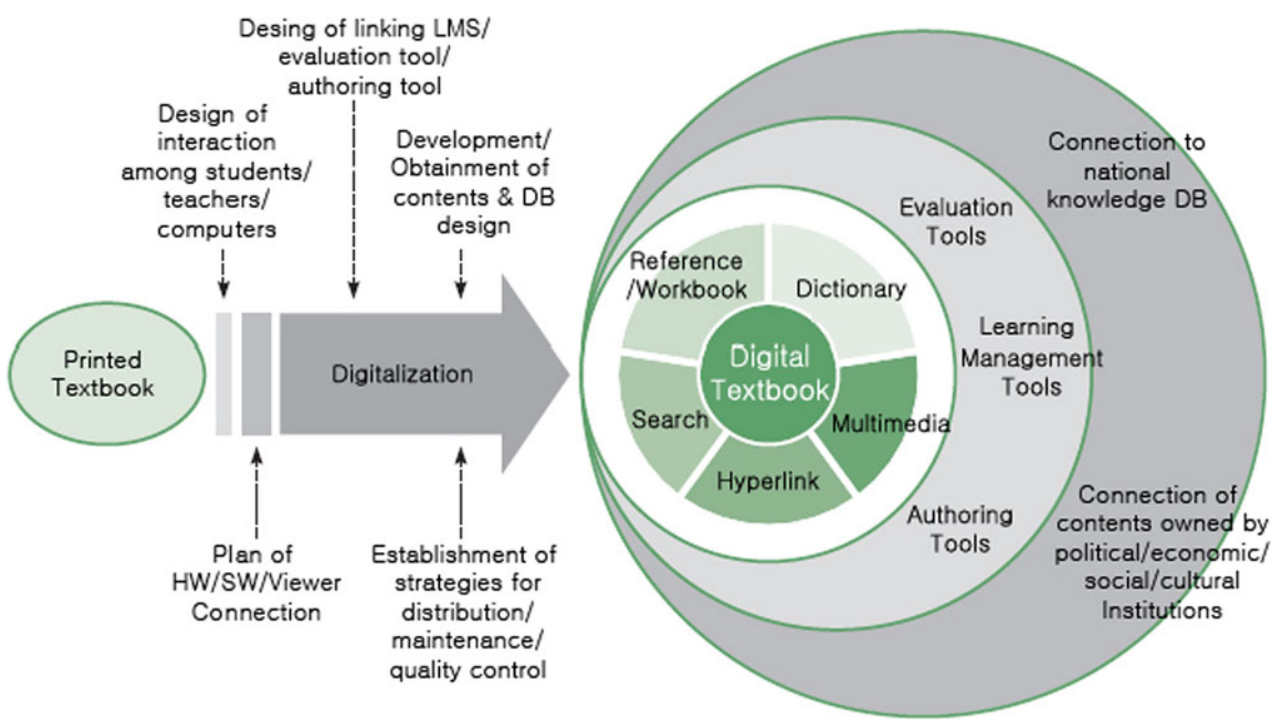

In Japan, Panasonic improved portability and user convenience by developing the dedicated electronic textbook terminal called $\Sigma$ Book; however, it had several problems, such as its incompatibility with existing content and the lack of a network function, as well as the fact that it only supported content designed for the $\Sigma$ Book.

Sony produced LIBRIE - a dedicated e-Book terminal capable of storing 20 books in its $10 \mathrm{Mb}$ basic memory, with excellent readability based on E-ink technology. In addition, new content can be downloaded conveniently with the network function.

NTT Docomo promoted the e-Book business by developing PDA-based e-Book terminals like Sigmarion III. Those products were designed to receive online services using various mobile communication technologies (digital mobile handset, PHS, packet communication, and FOMA). However, they suffered from a major limitation in that sending large amounts of data was more costly, as IEEE802.11 wireless LAN was not supported [27].

In France, Cytale developed an e-Book terminal called Cybook, which was equipped with a touch screen function, in December 2002, and provided a service consisting mainly of works of literature. Unlike the strategy of simply selling electronic book terminals to the public, this terminal was sold to people with at least one year's subscription, and 350 complete works and additional content could be downloaded from the Internet with a subscription. The Cybook service-which targets the public and doesn't consider school education - is costly because the initial terminal purchase expense is burdensome and content can only be purchased via the monthly subscription service [27].

In Singapore, the government carried out model operation for 160 first grade primary school students in 1999, based on the eduPAD project, in which the government (Ministry of Education and National Computer Board) and private enterprises (CET Technologies, Kent Ridge Digital Labs) invested 2.1 million dollars. The government provided the idea for eduPAD, the KRDL provided the software technology, CET provided the hardware, and various textbook publishers provided the content. eduPAD is a dedicated, portable terminal that offers various functions including multimedia, e-Book, pen input, character recognition, wireless network, and electronic dictionary. Students were asked to do research and homework in cooperation with other students, using eduPAD's wireless communication function. However, eduPAD failed because its Internet access was unstable in its early implementation stage, and because the learners didn't cooperate as planned [20].

Recently, Amazon Kindle and Apple's iPad emerge as substitutes for e-Book. They provide hardware functions to handle tens of Kbytes and Mbytes contents which are contained in PDF format e-Book. Due to the functions, two devices are appropriate for showing text-based digital documents. However, they seem to be insufficient to support multimedia contents, interactions between different learners, or an experience-oriented writing function.

\section{Digital textbook project in Korea}

Korea announced the "digital textbook commercialization promotion plan" in 2007, in order to lay a foundation for education designed to nurture the personnel required by the knowledge-based society via the development and dispersion of digital textbooks, and to raise the nation's status as a Strong Knowledge country by developing the national teaching and learning database and exporting content in the future. For this project, the MEST is charged with selecting sixteen policy tasks in six areas, and developing 25 types of digital textbook from 2007 to 2011 , for a pilot operation to 
Table 1 Status of digital textbook pilot operation in Korea

\begin{tabular}{|c|c|c|c|}
\hline Year & Linux Based & Windows Based & Total \\
\hline 2008 & $\begin{array}{l}20 \text { classes in } \\
8 \text { schools }\end{array}$ & $\begin{array}{l}61 \text { classes in } \\
23 \text { schools }\end{array}$ & $\begin{array}{l}81 \text { classes in } \\
23 \text { schools } \\
\text { ( } 8 \text { schools } \\
\text { overlap) }\end{array}$ \\
\hline 2009 & $\begin{array}{l}48 \text { classes in } \\
24 \text { schools }\end{array}$ & $\begin{array}{l}136 \text { classes in } \\
65 \text { schools }\end{array}$ & $\begin{array}{l}184 \text { classes in } \\
89 \text { schools }\end{array}$ \\
\hline Total & $\begin{array}{l}68 \text { classes in } \\
32 \text { schools }\end{array}$ & $\begin{array}{l}197 \text { classes in } \\
88 \text { schools }\end{array}$ & $\begin{array}{l}256 \text { classes in } \\
112 \text { schools } \\
\text { ( } 8 \text { schools } \\
\text { overlap) }\end{array}$ \\
\hline
\end{tabular}

be conducted in 100 research schools. The MEST will aim for commercialization after 2013 [10].

Reviewing the status promoted up to now, the prototype development project was conducted in 2007 before developing the main subjects of the digital textbooks, and the development of prototypes for nine subjects (1 unit amount) and three platforms has been completed. This approach is understandable in that the consent and verification of the interested parties can be obtained during the textbook development process, and the risk of failure can be minimized through the prior comparison and assessment of development display products, and the product development unit price can be estimated. In 2008, fifteen more schools were designated as research schools, besides the five existing research schools selected in 2007 , for a pilot test of the digital textbook (twenty research schools in total). The digital textbook environment-comprising one electronic board per class, a tablet PC for each student, a recharging box, and a wireless network - was created for the fifteen newly designated schools. Subsequently, 184 classes in 92 schools were provided with the digital textbook learning infrastructure as shown in Table 1. Some classes are now using the Windows platform, while others are using the open source-based platform. For this pilot project, the government invested about 4.6 million USD (2.4 million USD for Windows, 1.3 million USD for open source, and 0.9 million USD for shared servers) in infrastructure development, 1 million USD in S/W development ( 0.2 million USD for Windows, 0.8 million USD for open source), 5 million USD in contents development (approximately equivalent to 10.5 million USD) in 2008, and also invested about 7.8 million USD in infrastructure development, 1.1 million USD in S/W development, and 1.5 million USD in contents development in 2009 (approximately equivalent to 10.4 million U.S. dollars). The project is now being implemented at the national level [11].

\subsection{Status of digital textbook creation in Korea}

The digital textbook infrastructure is the component that implements the general u-Learning environment; it is com-

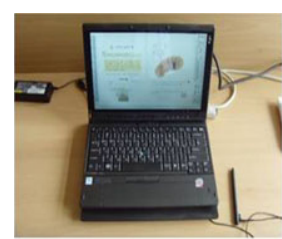

TabletPC

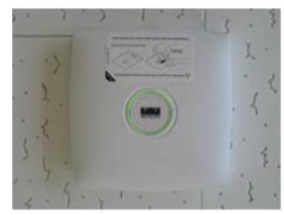

IEEE802.11G/NAP

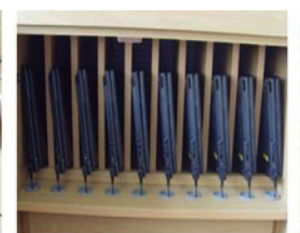

Battery Charger

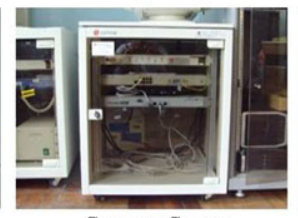

Contents Server

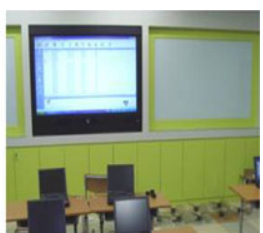

Electronic Board

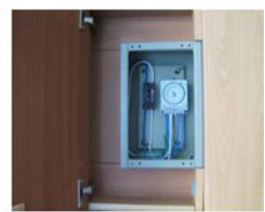

Power Timer
Fig. 2 Digital textbook infrastructure in class

posed of four elements-class infrastructure, digital textbook content, software, and network, which enable future u-Learning in the public education sector.

\subsubsection{Class infrastructure}

The infrastructure originally used for classes based around conventional textbooks was essentially composed of analogclass support media such as textbooks and blackboard. However, as shown in Fig. 2, digital textbook-based classes have been provided with portable $12^{\prime \prime}$ electromagnetic inductiontype Tablet PCs (TPC). The reason for introducing the TPC is not for just digitizing paperback book contents but for increasing the learning effect by providing multimedia contents such as high-quality video and audio materials, images, animations, virtual realities. It also provides learners with an opportunity for learning experiences, which is similar to those provided by paperback books. In order to provide sufficient TPC functions, it is required to ensure a hardware performance that is enough to run large-volume contents. In addition, e-Blackboards, which support touch screens sized $70^{\prime \prime}$ or more, have been replaced traditional blackboards.

The electronic blackboard can display the contents of digital textbooks or the content of a student's work when connected to the server. The student's tablet PC will need to be used for more than four hours per day on average, a duration which the current tablet PC battery capacity is unable to support. To cope with this problem, additional batteries are provided to students, and rechargers are provided in the classroom. For wireless Internet communication, three wireless access points are installed under the ceiling of the classroom, which is sufficient for Internet access by 30 digital textbook terminals [23].

\subsubsection{S/W}

The software used with the digital textbook runs the multimedia contents, and supports interaction among students 


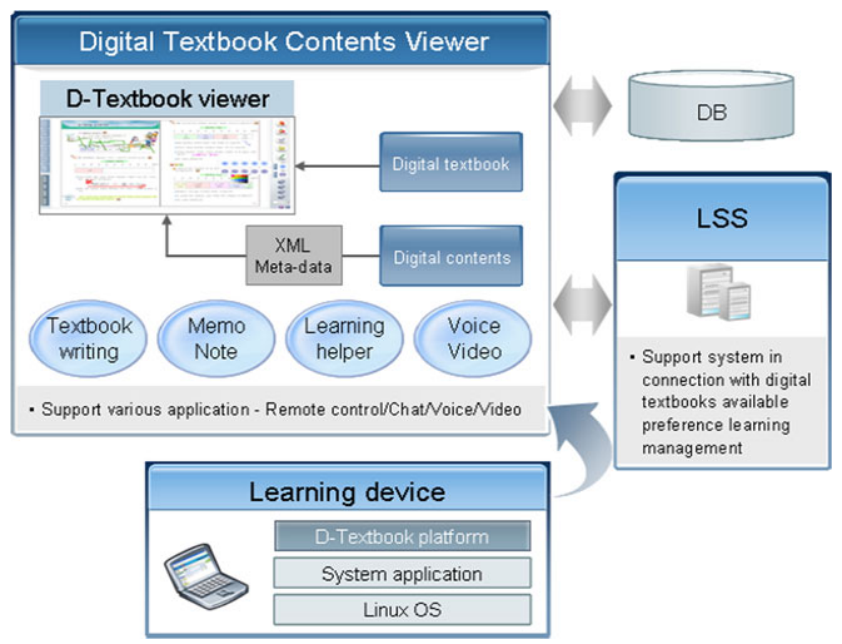

Fig. 3 Structure of the digital textbook system [23]

and between students and teachers, as well as providing various learning support functions. This software is largely composed of a digital textbook contents viewer and a learning support system, and runs on MS Windows or Linux. The digital contents viewer initially ran on MS Windows only in 2008, but additional development was carried out based on the open source, in order to reduce the license expense of the Windows operating system and the proprietary applications (MS Office, etc.), and to prevent dependency on specific technologies. Currently, two versions are available. This software was redeveloped by applying international standard technology, and by integrating the two versions into a single version, and was then applied to certain schools in a pilot operation. The learning support system is composed of the web-based LMS (Learning Management System) and the LCMS (Learning Contents Management System), and supports management of the student's learning history, assessment, learning level, and class operation as shown in Fig. 3.

\subsubsection{Textbook contents}

The digital textbook basically offers the same contents as the conventional textbook, but incorporates various other multimedia elements, so that students can engage in selfdriven study. Currently, the digital textbook is provided for six subjects in fifth-grade primary schools (Korean, English, Mathematics, Society, Science, and Music) and five subjects in the sixth grade (Korea, Mathematics, Society, Science, and English). As a pilot project, some sixth-grade classes are provided with English contents that can be learned by level.

The contents of digital textbooks inherently consist of high-quality multimedia and their size ranges from a minimum of 1 Gigabyte to a maximum of 5 Gigabytes for each subject. The entire size is 1.5 Gbytes, and if its contents for

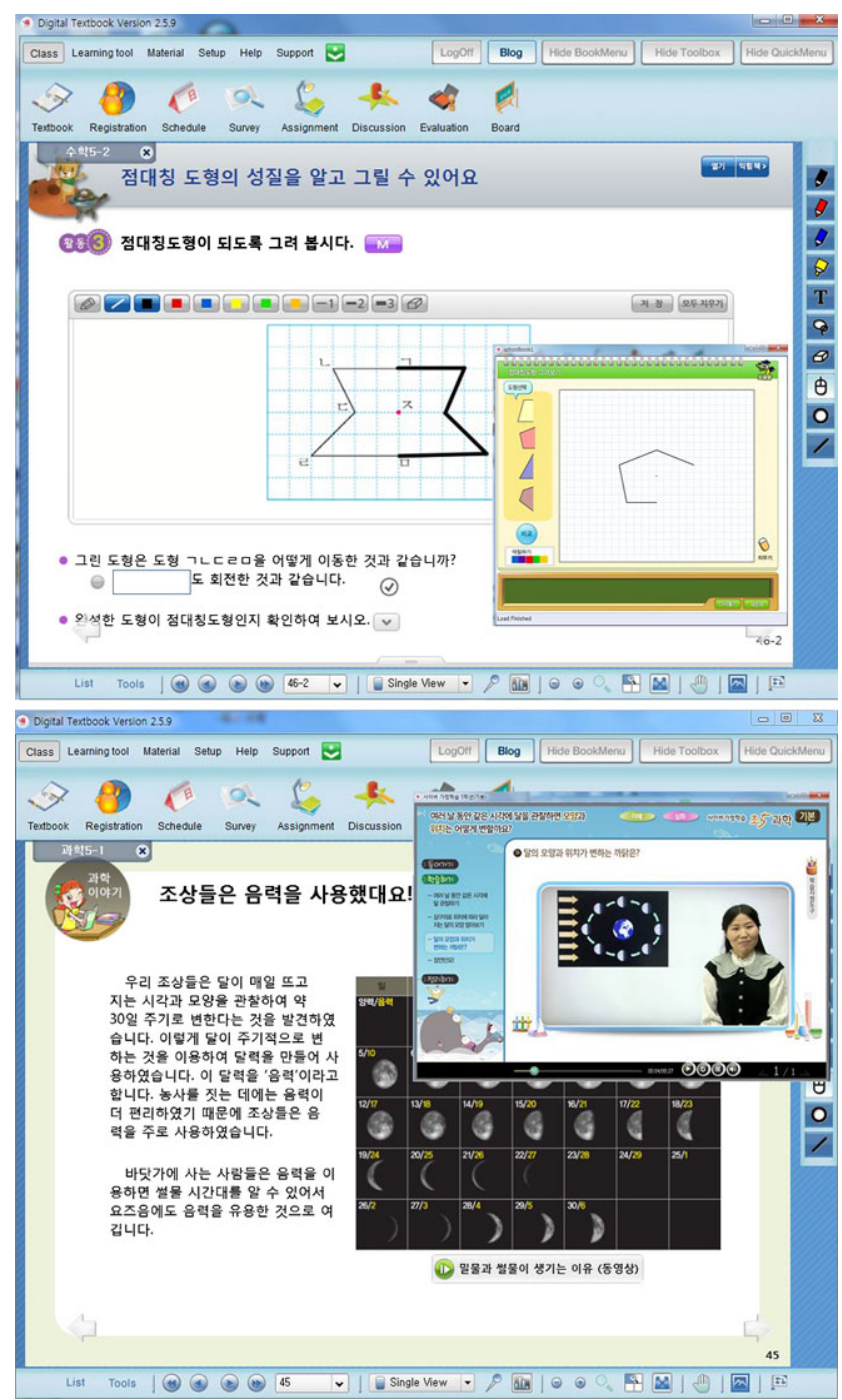

Fig. 4 Screenshot of the digital textbook contents and contents viewer [23]

the English class of the 5th year of elementary school, which comprises 64 lectures in all, then the volume of contents allocated to each lecture will usually be 24 Megabytes. Figure 4 shows screenshot of the digital textbook contents and contents viewer.

Classes provided at schools may require references to precedent contents, which are different from the way of reading books. Downloading contents for the classes may impose a heavy burden on the computer network. To resolve this problem, in digital textbook-based classes in Korea, the contents of each subject are stored in TPC, while the contents to be updated are downloaded via the network. This allows the school to provide optimal digital textbook classes at a lower cost. Students are able to search information through the Internet and use verified learning materials by Edunet, in addition to existing digital textbook contents. 
Fig. 5 Diagram showing the configuration of the entire network [23]

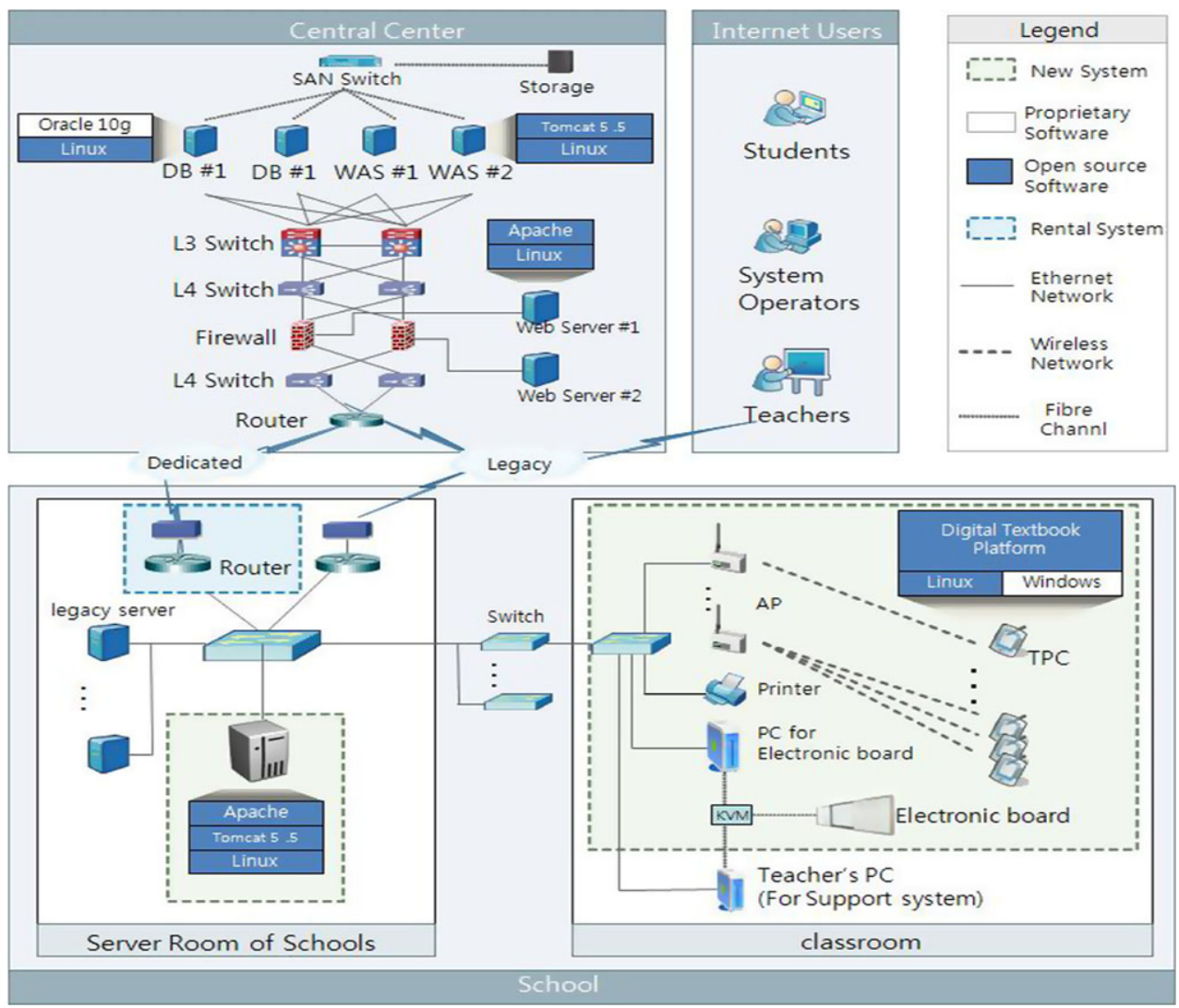

\subsubsection{Network}

The network originally used by schools was a national closed network known as the "school network". This school network had the advantage of blocking illegal access from the outside and preventing disclosure of the students' profiles. However, it could not guarantee a reasonable access speed when accessing the Internet, due to the low bandwidth. To overcome this shortcoming, the digital textbook project configured the network in such a Fig. 5 that servers storing important information were connected to the existing school network while only some data were connected to the dedicated server for digital textbooks. Also, the FTTH-based dedicated Internet network offered by the general ISP was deployed inside the schools, so that the Internet could be accessed directly. This enabled the endusers (students) to access the Internet via the wireless access point [16]. Using this network configuration, the various problems experienced by the twenty model research schools in 2008 - such as the difficulty in downloading the contents due to overload caused by ever expanding volume of traffic, the increase in line speed to accommodate the rising volume of network traffic, and the extra cost of the network line needed to expand the project-were resolved Currently, the integrated digital textbook infrastructure system is being run via the interface with the ex- isting infrastructure network. In addition, connection interruption is minimized while using the system because the design was based on user's movement at its initial stage [11].

However, the bandwidth of the dedicated line between schools and the ISP remains at about $10 \mathrm{M} \sim 30 \mathrm{Mbps}$ due to the problem of high cost, which makes additional investment and a different approach necessary. Also, the students' terminals currently support IEEE801-based wireless LAN only, which makes a smooth digital textbook service impossible in the shadow area of the wireless access point or when on the move [23].

Traffic which is generated during a digital textbook class is divided into three types: first, traffic produced while the Edunet, a closed network, communicates with the main server; second, traffic generated in the school intranet; and lastly, traffic produced over the Internet. The traffic produced over the school intranet is beyond the scope of this study and accordingly is not discussed here.

The analysis of the traffic generated during communication with the main server shows that students downloaded their digital textbook contents in TPC. Due to this propensity, Table 2 shows the daily traffic is about 10 Megabytes, which is not so heavy. It includes the login information for verifying the identity of the user.

However, as shown in Table 3, the analysis of the traffic produced over the Internet shows the 10 30 Mbps capac- 
Table 2 Daily Average Traffic produced over a 5-week period during Communication with the Master Server

\begin{tabular}{ll}
\hline Week & Traffic \\
\hline 1st week & 10.7 Mbyte \\
2nd week & 10.4 Mbyte \\
3rd week & 10.5 Mbyte \\
4th week & 10.3 Mbyte \\
5th week & 10.0 Mbyte \\
\hline
\end{tabular}

Table 3 Bandwidths required for each Service and No. of Classes ${ }^{\mathrm{a}}$

\begin{tabular}{llll}
\hline Service Model & 1 class & 8 classes & 24 classes \\
\hline $\begin{array}{l}\text { Download based } \\
\text { on school servers }\end{array}$ & $21 \mathrm{Mbps}$ & $168 \mathrm{Mbps}$ & $504 \mathrm{Mbps}$ \\
Cloud education & $16.8 \mathrm{Mbps}$ & $134.4 \mathrm{Mbps}$ & $403 \mathrm{Mbps}$ \\
CDN & $21 \mathrm{Mbps}$ & $168 \mathrm{Mbps}$ & $504 \mathrm{Mbps}$ \\
\hline
\end{tabular}

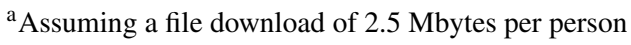

ity of lines for Internet access is insufficient, but the traffic depends on the size of schools [23]. This is because the students access the Internet on their digital textbook in the same way on a common PC. Currently, students have to download the entire contents in advance. However, in the ubiquitous learning environment, they should be allowed to download digital contents anytime and anywhere over the network. KERIS conducted the research on commercialization of digital textbooks in the future. The authors suggested the service model using contents server, the SBC (Server Based Computing)-based Cloud Education service model, and the CDN (Contents Delivery Network) service model. The traffic volumes required by three models are as follows [24].

\section{Selecting a suitable wireless network for the digital textbook}

\subsection{Wireless network status in Korea}

This chapter briefly outlines the status of three wireless data network that are deployed and used in Korea, namely wireless LAN, mobile WiMax, and HSDPA (High Speed Downlink Packet Access).

First, wireless LAN enables a wireless Internet access service that guarantees low-speed mobility (i.e. walking speed). KT has offered the service in Korea using the ISM frequency bandwidth $(2.4 \mathrm{GHz})$ since February 2002, securing 346,000 subscribers as of 2008 [29]. Approximately 13,000 hot spots (zones where wireless LAN is available) have been established nationwide, including airports, university areas, enterprises, and public places [14].
Second, mobile WiMAX, a mobile Internet access service, ensures mobility at speeds in excess of $120 \mathrm{~km}$ per hour. KT and SK Telecom have offered this service since June 2006 in Korea. KT secured 160,000 subscribers by providing the service in 19 cities including Seoul, Gyeonggi, and Incheon, while SK Telecom secured 11,000 subscribers by providing the service in 42 cities throughout the country, including Seoul, Gyeonggi, and Incheon [29].

Third, the HSDPA service enables voice calls and lowspeed data communication while on the move. KT and SK Telecom have offered this service since May 2006, and expanded the HSDPA service area to 84 major cities in March 2007. As of 2008, KT had secured 8,266,000 subscribers and SK Telecom, 8,233,000 subscribers [29].

\subsection{Criteria for a suitable wireless network for the digital} textbook project

The current digital textbook project uses wireless LAN as the primary wireless network, which is acceptable in that it can overcome the spatial limitation of the fixed line network and provides a better data rate than other wireless networks. However, it has been pointed out that wireless LAN is weak in terms of mobility and security [13]. For instance, wireless LAN technology can be appropriate if the digital textbook is used as a learning material inside the classroom. However, if a class is given outside the classroom, for example, as a field study, only the digital textbook contents stored in the tablet PC can be used, while the use of auxiliary or supplementary data via the Internet or discussion among students cannot be performed properly. Therefore, we need to evaluate which wireless network is desirable for the digital textbook, based on diverse and comprehensive criteria.

As yet, no studies have been conducted on which wireless network is appropriate for the digital textbook project among the various wireless networks. In this chapter, general criteria are applied in order to review the wireless network assessment criteria, instead of criteria specific to the digital textbook project.

The Information System Auditing Guide [21] lists system performance, availability and scalability, security and stability, and ease and flexibility of operation management as the criteria that should be applied when designing or developing a network system. In addition, the u-City IT Infrastructure Creation Guideline (Details) [22] presents seven criteria, including mobility and ensuring proper bandwidth, as the desirable design direction of the wireless internal network using the wireless LAN, as shown in Table 4. Both of two criteria recommend the application of similar criteria regarding performance (ensuring proper bandwidth), availability and scalability (scalability), security and stability (security), and ease and flexibility of operation management (easiness of installation), whereas the u-City IT Infrastructure Creation Guideline (Details) [22] presents more items 
Table 4 Desirable design direction for the wireless internal network [22]

\begin{tabular}{|c|c|c|}
\hline Classification & Details & Remarks \\
\hline Mobility & $\begin{array}{l}\text { It was provided that terminals of the wireless LAN can be enables } \\
\text { a seamless wireless Internet access to AP (Access Point) when on } \\
\text { the move between buildings or inside of building }\end{array}$ & $\begin{array}{l}\text { Handover functions of } \\
\text { the wireless LAN } \\
\text { Mobile IP }\end{array}$ \\
\hline $\begin{array}{l}\text { Ensuring proper } \\
\text { bandwidth }\end{array}$ & Cell design which is reflect on the estimate user or traffic per AP & \\
\hline $\begin{array}{l}\text { Easiness of installation } \\
\text { and scalability }\end{array}$ & $\begin{array}{l}\text { Easiness of installation of additional AP or Scalability of the } \\
\text { wireless LAN }\end{array}$ & \\
\hline \multirow[t]{2}{*}{ Security } & Encryption function for preventing wiretapping & IEEE $802.11 \mathrm{i}$ \\
\hline & Authentication function for the user which is granted & IEEE $802.11 \mathrm{x}$ \\
\hline $\begin{array}{l}\text { Standardization and } \\
\text { compatibility }\end{array}$ & To secure Compatibility by Standards of the wireless LAN & $\begin{array}{l}\text { IEEE } 802.11 \text { series of } \\
\text { standards }\end{array}$ \\
\hline \multirow[t]{3}{*}{ Cell design } & $\begin{array}{l}\text { To exclude drop and interruptions of channel using no overlapping } \\
\text { channel }\end{array}$ & \\
\hline & $\begin{array}{l}\text { Cell design which is considers drop and interruptions of channel or } \\
\text { Attenuation of signal by surroundings }\end{array}$ & \\
\hline & Cell overlapping for mobility of terminals & \\
\hline QoS & $\begin{array}{l}\text { To provide to QoS supporting function for Series of traffic of the } \\
\text { wireless LAN }\end{array}$ & IEEE $802.11 \mathrm{e}$ \\
\hline
\end{tabular}

to consider when designing the wireless network, including mobility, standardization and compatibility, cell design, and QoS.

This study compares the strengths and weaknesses of the wireless networks currently in use in Korea (wireless LAN, HSDPA, and mobile WiMax) and reviews which wireless network is appropriate for the digital textbook project, by focusing on the items commonly presented by two criteria, including system performance (ensuring proper bandwidth), availability and scalability (scalability), security and stability (security), and ease and flexibility of operation management (easiness of installation). In addition, efforts are being made to improve practicality by additionally reviewing the economic aspect of network establishment and operation, which is meaningful at the working level, even though it is not presented as the review item by two criteria.

\subsection{Performance of the wireless network system}

First, when reviewing the three wireless networks from the perspective of system performance in Table 5, wireless LAN enables the high-speed Internet service within a certain distance from the access point installation area. It can provide a speed of up to $54 \mathrm{Mbps}$, but this may drop and interruptions may occur if the number of users increases due to frequency sharing among users [13]. In addition, the radio reaching distance is limited to approximately 300 meters, thus necessitating additional stations to expand coverage. Also, only limited mobility is provided, as handoff is not supported [13].
HSDPA has evolved from WCDMA (3rd generation service) in such a way that faster data communication can be guaranteed. It supports a data rate of up to $14 \mathrm{Mbps}$. HSDPA ensures high mobility as it has the characteristics of mobile communication and supports relatively wide cell coverage, which requires fewer stations for the expansion of coverage than other networks. However, the data rate is much lower than others.

Mobile WiMAX supports broadband Internet access in a wireless environment like the high-speed Internet service, and enables uninterrupted wireless Internet access faster than 1 Mbps within downtown areas. In addition, it is positioned between wireless LAN and HSDPA in terms of its data rate, mobility, and cell coverage. As a result, it is securing its own independent area as a niche market [12].

When reviewing the average data rates actually provided to subscribers while running the three wireless technologies, they are seen to differ from the theoretical maximum data rate. For instance, KT actually provides data rates of $23 \mathrm{Mbps}$ for wireless LAN, $1 \mathrm{Mbps}$ for HSDPA and $3 \mathrm{Mbps}$ for mobile WiMAX [14]. The quality measurement result of the Korea Communications Commission (2008) also shows that the average data rate of the mobile operators' HSDPA was 1.35 Mbps (SKT) and 1.135 Mbps (KT), respectively [9]. When we compare these average data rates with the data rate of the wireless LAN measured at the digital textbook model school (around $23 \mathrm{Mbps}$ ), we can see that the data rates of HSDPA and mobile WiMAX are somewhat lower than that of wireless LAN.

However, it would be difficult for us to determine whether one particular wireless network technology is su- 
Table 5 Comparison of wireless networks $[14,15]$

\begin{tabular}{llll}
\hline Classification & Wireless LAN & HSDPA & Mobile WiMAX \\
\hline Maximum data rate & $11 \mathrm{Mb} / \mathrm{s}(802.11 \mathrm{~b})$ & Download: $14 \mathrm{Mb} / \mathrm{s}$ & Download: $18.4 \mathrm{Mb} / \mathrm{s}$ \\
& $54 \mathrm{Mb} / \mathrm{s}(802.11 \mathrm{a}, \mathrm{g})$ & Upload: $2 \mathrm{Mb} / \mathrm{s}$ & Upload: $6.1 \mathrm{Mb} / \mathrm{s}$ \\
Average data rates & $23 \mathrm{Mb} / \mathrm{s}$ & Download: $1.0 \mathrm{Mb} / \mathrm{s}$ & Download: $3.0 \mathrm{Mb} / \mathrm{s}$ \\
& & Upload: $0.3 \mathrm{Mb} / \mathrm{s}$ & Upload: $1.2 \mathrm{Mb} / \mathrm{s}$ \\
Channel bandwidth & $22 \mathrm{MHz}$ & $5 \mathrm{MHz}$ & $8.75 \mathrm{MHz}$ \\
Mobility & Low $($ walking speed) & High $(250 \mathrm{~km} / \mathrm{h})$ & Middle $(120 \mathrm{~km} / \mathrm{h})$ \\
Coverage & Narrow $(50-100 \mathrm{~m})$ & Wide $(3-4 \mathrm{~km})$ & Middle $(1 \mathrm{~km})$ \\
Standard & IEEE 802.11 & $3 \mathrm{GPP}$ WCDMA & IEEE $802.16 \mathrm{e}$ \\
\hline
\end{tabular}

perior to the others when applied to the digital textbook project, simply based on the differences in mobility and data rate. The reason for this is that the current digital textbook model project doesn't require significantly better mobility or faster network speed, because the digital textbook is saved in the tablet PC in advance and then played back in class.

However, in a mobile learning environment, students move to a place other than stay in the classroom. The high performance network is required for easy downloads of large-volume digital textbook contents and learning materials in the environment. The choice for the network depends on the preference between a wireless LAN, which is focused on a higher data transfer rate and HSDPA or Mobile WiMAX, which are characterized by their mobility.

\subsection{Availability and scalability, and easiness of operation management}

It was found that HSDPA, provided as a nationwide service since 2007, holds a dominant position in terms of availability or accessibility. KT invested 539 million USD in the mobile WiMAX service and secured $46.4 \%$ service coverage (based on population), whereas SK Telecom secured $43.6 \%$ population service coverage with an investment of 417 million USD between 2006 and 2008. The Korea Communications Commission plans to establish the network in 84 major cities throughout the country with either a single communication operator or several operators [8]. Wireless LAN cannot cover wide areas due to its narrow cell coverage, even though 13,000 hot-spot zones are available nationwide for major public facilities such as stations, airports, and hotels. Therefore, access points need to be installed in all target schools for digital textbook operation inside the schools.

In addition, from the perspective of scalability, which implies that changes and additions of equipment should be easy when expanding network capacity in line with the increase in its utilization, wireless LAN is relatively easy to expand, compared with HSDPA and mobile WiMAX, because it can be installed and changed internally. Scalability is required because communication service providers are likely to take a passive attitude toward capacity expansion for individual schools (digital textbook model schools) without the imposition of an additional charge, as they emphasize profit. Therefore, policy support may be needed to cover the costs incurred by increasing capacity, such as providing government subsidies or placing the obligation to increase capacity on the communication service providers. Wireless LAN can take longer when expanding capacity, because the procedure of securing the budget for facility improvement must be prepared in advance, given that the digital textbook project is a public agency project supported by a governmental budget.

There are differences in the methods of managing the operation of commercial networks (HSDPA or mobile WiMAX) and internal networks (wireless LAN). Dedicated network operation organizations are available for the commercial network, and quick service recovery is guaranteed according to the user agreement. In practice, however, the user agreement for KT's mobile WiMAX service stipulates that KT should compensate the user in the event of an interruption of service. If KT cannot resume the service within 3 hours or if the service is interrupted or unavailable for longer than 12 accumulated hours in a given month after receiving the customer's notice of service interruption, and which is not caused by the customer's fault, KT is legally obliged to pay back three times the average use fee to the customer. Conversely, the digital textbook project, which focuses on wireless LAN, requires the equipment vendor to create a nationwide customer service center environment, to run a field support service, and to guarantee free (12 months after installation) or paid after-service [11].

\subsection{Security}

Wireless LAN, which is used by the digital textbook project in Korea, is known to have several security vulnerabilities. Vulnerabilities in the wireless Internet service can be classed either as problems with the authentication process when accessing the wireless network, or as problems relating to the vulnerable encryption of wireless transmission data [12]. We can connect the access point during the user authentication 
Table 6 Comparison of the development and usage costs of wireless networks: Based on 2 classes in 1 school

\begin{tabular}{|c|c|c|c|c|}
\hline \multirow[t]{2}{*}{ Classification } & \multirow[t]{2}{*}{ Wireless LAN } & \multirow[t]{2}{*}{ HSDPA } & \multicolumn{2}{|l|}{ Mobile WiMAX } \\
\hline & & & Commercialized & Self-constructed $^{1}$ \\
\hline \multirow[t]{2}{*}{ Construction cost } & $\begin{array}{l}\text { AP: } 313 \text { USD } \times 4= \\
1,252 \text { USD }\end{array}$ & None & \multirow{2}{*}{$\begin{array}{l}\text { Small Relay: } \\
235 \text { USD } \times 2 \text { classes } \\
=470 \text { USD }\end{array}$} & $\begin{array}{l}\text { Femtocell: } 392 \text { USD } \times \\
2 \text { classes }=784 \text { USD }\end{array}$ \\
\hline & $\begin{array}{l}\text { PoE: } 78 \text { USD } \times 4= \\
312 \text { USD }\end{array}$ & & & $\begin{array}{l}\text { PoE: } 235 \text { USD } \times \\
2 \text { classes }=470 \text { USD }\end{array}$ \\
\hline Operational cost & $\begin{array}{l}\text { for each line: } \\
16 \text { USD } \times 4 \text { lines } \times \\
12 \text { months }= \\
768 \text { USD }\end{array}$ & None & None & $\begin{array}{l}100 \text { M released line: } \\
392 \text { USD/month } \times \\
12 \text { month }=4,704 \text { USD }\end{array}$ \\
\hline Service charge & $\begin{array}{l}80 \text { people } \times \\
6.3 \text { USD/ID } \times \\
12 \text { month }= \\
6,048 \text { USD }\end{array}$ & $\begin{array}{l}80 \text { people } \times \\
23.5 \text { USD/ID } \times \\
12 \text { month }= \\
22,560 \text { USD }\end{array}$ & $\begin{array}{l}80 \text { people } \times \\
16 \text { USD/ID } \times \\
12 \text { month }= \\
15,360 \text { USD }\end{array}$ & None \\
\hline $\begin{array}{l}\text { First one year } \\
\text { (including } \\
\text { construction fee) }\end{array}$ & 8,380 USD & 22,560 USD & 15,830 USD & 5,958 USD \\
\hline
\end{tabular}

The data is based on the estimated amount, and may differ from the actual price

The subscription fee for mobile WiMAX is 16 USD up to $30 \mathrm{~Gb}$, whereas HSDPA allows up to $2 \mathrm{~Gb}$ download

Internal mobile WiMAX cannot be used now, as the policy doesn't allow its establishment

process by receiving the SSID (Service Set Identifier) broadcasted by the access point, provided we have a wireless LAN card, or masquerade as others by eavesdropping on the SSID or MAC. Even encryption is vulnerable because many WEP (Wired Equivalent Privacy) crack tools are opened to the public [7]. Security threats to wireless LAN can be summarized as (1) denial of service attacks using the management frame; (2) eavesdropping on user traffic using the onedirectional authentication method; (3) creation of service confusion using the masqueraded AP; (4) hijacking of the session or authorized user; and (5) eavesdropping on communication content using the man-in-the-middle attack [12]. It has been pointed out that, basically, the following measures are required to improve the security vulnerabilities of the wireless LAN service: (1) separate the operation of wired and wireless LAN; (2) define the status and criteria of Internet access via wireless LAN; (3) change the wireless equipment password periodically; (4) designate a wireless LAN administrator; and (5) conduct periodic checks using the wireless LAN security checklist [7].

In practice, we cannot say that there is no security threat in mobile WiMAX that WiMAX that is similar to the wireless LAN, but it is expected that a significant number of security threats could be resolved using the PKMv3 security technology standard adopted by mobile WiMAX [12]. HSDPA has been evaluated as a network that is relatively free from security threats, as it is a closed network.

The current digital textbook project operates separate wire/wireless LAN in its network inside the schools, and only opinions about classes are exchanged among students or between teachers and students in the wireless LAN segment, while data concerning school administration is excluded. As a result, it can be said that the security vulnerabilities of the wireless LAN service have been resolved to a great extent.

However, private information could be exposed to leakage in the case of an intrusion into the main server or LMS (Learning Management System) which supports the learning history, evaluation, learning levels, and class operation/management. Thus, in order to enhance security against unauthorized access to these systems, the user's terminal should provide authentication using either a WLAN authentication server (RADIUS) or a security authentication program such as Multibiometric. Appointing wireless LAN managers and establishing a WLAN security checklist are also required for improving security.

\subsection{Economic feasibility of network establishment and operation}

When the cost of establishing and operating the network is taken into consideration, greater expenditure is required for the wireless LAN, mobile WiMAX commercial, and HSDPA networks, in that order as shown in Table 6.

Of the three network technologies, it was found that the wireless LAN network/service would require the lowest establishment and operation expenses in the first year after its establishment $(8,339$ USD). The subscription fee accounts for the largest share (72\%) when wireless LAN is used, because the cost of network establishment can be re- 
duced by using the high-speed Internet network already installed inside the school rather than by installing a separate, dedicated line. However, wireless LAN has the shortcomings of limited coverage (within 100 meters around the AP) and immobility due to the limited throughput of the equipment.

It was also found that the cost of using the HSDPA network is higher than that of the other two wireless networks (22,571 USD per year/school). The HSDPA network provides the benefit that no additional establishment cost is required for the digital textbook project, as the commercial network is available throughout the country. However, it is not suitable for high-speed wireless data communication because the frequency resources have to be limited in order to provide the wireless data service, because the limited frequency resource has to be shared by the mobile voice communication and mobile data services. In addition, if the amount of data used exceeds 2 Gbytes per month, an additional charge will be imposed, making it an unavailable option for most schools with a limited budget.

Lastly, it was found that the network establishment/operation cost of using the mobile WiMAX commercial network is 15,517 USD for the first year, which is 1.86 times more than that of the wireless LAN network. Therefore, it is not an appropriate option in terms of cost. The difference in cost may stem from the network subscription fee. Consequently, if a special discount system can be provided for the digital textbook project, the difference in cost between the two network options could be narrowed. The problem of using the mobile WiMAX commercial network is that some schools cannot use the mobile WiMAX network because it has not yet been deployed throughout the entire country.

On the other hand, establishing the internal mobile WiMAX network with Femto cell equipment can be considered as a viable method of reducing the cost of establishing the network for the digital textbook project. In this case, it was found that a $28.5 \%$ greater saving could be made compared to wireless LAN establishment and operation, because the network subscription fee, which occupies a significant proportion of the network cost, can be saved. However, establishment of the internal mobile WiMAX network is prohibited in Korea due to congestion among macro stations and the likelihood of decreased revenue among providers of the mobile WiMAX service. Nevertheless, given that mobile WiMAX Femto cell technology is mature enough to be applied to the digital textbook project (as proven by the release of a pilot product of the mobile WiMAX Femto cell) and the digital textbook project has the characteristics of public welfare (educational development), it would be worthwhile to consider allowing the installation and operation of the internal mobile WiMAX network just for public projects like the digital textbook project.

\subsection{Implication}

In this chapter, the three technologies available for the digital textbook project are reviewed from various perspectives. In summary, the wireless LAN technology currently in use has a relative advantage in terms of its data rate and costeffectiveness, whereas HSDPA is strong in terms of mobility, security, and availability. On the other hand, the mobile WiMAX network is located midway between wireless LAN and HSDPA as shown in Table 7.

Therefore, it is necessary to reconsider the future policy direction of the digital textbook project by taking into account the different features these wireless technologies.

For instance, the digital textbook business has been developing from e-Learning to $\mathrm{u}$-Learning or $\mathrm{m}$-Learning. The potential increase of digital contents driven by new technologies is taken into consideration. It may be desirable to adopt Mobile WiMAX, which guarantees mobility and transfer rate, or HSDPA, which emphasizes mobility and security for handling large amount of digital contents.

\section{Conclusion}

This paper reviews the content of the digital textbook project, which is being operated as a pilot model in Korea, and selection criteria for the wireless network to be applied to this project.

The digital textbook is a suitable medium for the generation of creative knowledge and the development of students' competence, for the provision of customized education that fits each individual's specific needs, and for the ongoing changes in educational needs such as the enhancement of self-driven learning capability [19]. Korea has been developing digital textbooks (with a budget of 27.3 billion) since 2008; has created a wireless network environment for 256 classes in 112 schools using wireless LAN technology; and is facilitating classes based around the use of digital textbooks by distributing the required items of equipment, including electronic blackboards and tablet PCs.

At present, it is believed that wireless LAN was selected for the digital textbook project in Korea because it provides a better data rate and greater cost-effectiveness than the two other wireless network technologies (HSDPA and mobile WiMAX), when assessed according to various wireless network assessment criteria. However, wireless LAN technology is inferior to the other technologies in terms of mobility and security.

Considering the Korean case, the policy implications for the digital textbook project in Korea are as follows. First, interest in and policy support for the mobile WiMAX technology is needed when we consider the developmental direction and technical development trend of the digital textbook project. In line with the development of information 
Table 7 Comparison of wireless network technologies

\begin{tabular}{|c|c|c|c|c|}
\hline \multicolumn{2}{|c|}{ Wireless network assessment criteria } & \multirow{2}{*}{$\begin{array}{l}\text { Wireless LAN } \\
1\end{array}$} & \multirow{2}{*}{$\frac{\text { HSDPA }}{3}$} & \multirow{2}{*}{$\frac{\text { Mobile WiMAX }}{2}$} \\
\hline System & Data rate & & & \\
\hline performance & Mobility & 3 & 1 & 2 \\
\hline \multirow{5}{*}{$\begin{array}{l}\text { System } \\
\text { management }\end{array}$} & Security & 3 & 1 & 2 \\
\hline & Cost-effectiveness & 1 & 3 & 2 \\
\hline & Availability & 3 & 1 & 2 \\
\hline & Scalability & 2 & 2 & 2 \\
\hline & $\begin{array}{l}\text { Ease and flexibility of } \\
\text { operation management }\end{array}$ & 1 & 1 & 1 \\
\hline
\end{tabular}

1 -excellent, 2-normal, 3 -insufficient different wireless networks. As described before, each wireless network has unique features and strengths, and seems to be evolving in such a way that these features can be maintained. For instance, wireless LAN is likely to evolve into the mesh network that supplements mobility, whereas mobile WiMAX will prepare the standard that allows improvement of the data rate from $34.4 \mathrm{Mbps}$ to $128 \mathrm{Mbps}$ (802.16e rel.1.5) by 2010. Also, the HSPA+ and LET commercial service-HSDPA family wireless data network will also be introduced. It seems that the wireless technology needed for the future digital textbook project will be developed in such a way that it can meet the requirements of data rate and mobility via the interface between the different networks. The future digital textbook will enable u-Learning in the true sense of the word, by connecting various wireless networks seamlessly. Therefore, technological development and policy support are required to enable the interface between the various wireless networks.

To conclude, a counter-argument could be advanced with regard to the appropriateness of the network assessment criteria, as this study is simply an experimental research regarding the assessment criteria for wireless network selection. A lively discussion is expected based on more complete, subsequent study regarding which network (and with what properties) would be more desirable and appropriate.

Acknowledgements This research was supported by the KCC (Korea Communications Commission), Korea, under the CPRC (Communications Policy Research Center) support program supervised by the NIPA (National IT Industry Promotion Agency) (nipa-2010-C10911001-0005).

Open Access This article is distributed under the terms of the Creative Commons Attribution License which permits any use, distribution, and reproduction in any medium, provided the original author(s) and the source are credited.

\section{References}

1. Byun, H. S., Yoo, K. H., Yoo, J. S., Choi, C. Y., \& Park, S. H. (2005). A study on standardization of digital textbooks, Korea Education \& Research Information Service (Research Reports, CR 2005-22). 
2. Electronics and Telecommunications Research Institute (2009). ETRI, exporting Wibro to middle Asia, May 2009.

3. Houston, D. (2006). Mobile education: opportunities \& strategies for wireless technology \& application. Juniper Research Limited, UK.

4. Internet indicators: subscribers, users and broadband subscribers, International Telecommunication Union Internet Information (2007). http://www.itu.int/ITU-D/icteye/Reporting/ ShowReportFrame.aspx?ReportName=/WTI/ InformationTechnologyPublic\&RP_int Year=2007\&RP_ intLanguageID $=1$.

5. Jeong, E.-S., Song, Y.-H., \& Chae, J.-B. (2008). A study on the digital textbook development strategies and development direction. In Korea computer congress 2008 (Vol. 35, No. 1(B), pp. 230-235).

6. Kim, U. d., Lee, T. K., \& Park, C. M. (2005). A study on constructing the education environment based on u-learning. Journal of Korean Society for Internet Information, 6(2), 249-253.

7. Korea Communications Commission, Korea Information Security Agency (2008). Security technology manual of wireless LAN, 2008.11.

8. Korea Communications Commission (2009). Korea Communications Commission announced 'Three major policy directions and eight tasks for promoting WiBro services'.

9. Korea Communications Commission (2009). Service quality of $3 G$ mobile phone? Yes!!, 2009.05.19

10. Korea Education \& Research Information Service (2008). Adapting education to the information age.

11. Korea Education and Research Information Service (2009). A request for proposal for supporting establishment of infrastructures and service operation of experimental schools with digital textbooks.

12. Korea Information Security Agency (2006). Security technology manual of mobile WiMAX, 2006.8.

13. Korea Information Society Development Institute (2009). Assessment of competitive circumstance of telecommunications market in 2008, 2009.12.

14. Korea Telecom (2010). http://www.show.co.kr/index.asp?code= WAA0000.

15. Lee, D.-H., Lee, H.-J., Lee, Y.-W., \& Shin, D.-H. (2006). Wireless broadband services and network management system in KT. International Journal of Network Management, 2006(16), 429-442.

16. Lee, B. G., Kim, S. J., Park, K. C., \& Jeong, E. S. (2009). Critical success factors and innovative practices for using the digital textbook in u-learning environment. In KSII: The first international conference on Internet 2009, Dec. 2009.

17. Lee, Y. J., You, H. C., Park, I., Kim, H., Lim, B., Jung, J., \& Ko, B. S. (2009). Portable learning device, Korea Education \& Research Information Service, 2009.9.

18. Mahmoud, S. S. (2008). A proposed model for distribution ecourses content through mobile technology architectures. World Academy of Science, Engineering and Technology, 27, 274-289.

19. Ministry of Education Science and Technology, Korea Education \& Research Information Service (2007). Adapting education to the information age.

20. Ministry of Education, Singapore, eduPAD school-industry partnership scheme project. http://www.moe.gov.sg/media/press/ 1999/pr990922a.htm.

21. National Information Society Agency (2006). The information system auditing guide.

22. National Information Society Agency (2009). Detailed guideline of u-City IT infrastructure construction v.2.0 (Vol. 4, p. 57).

23. National IT Industry Promotion Agency, Korea Education \& Research Information Service (2009). 2009 report on results: infrastructures of digital text services using open-source software.
24. National IT Industry Promotion Agency, Korea Education \& Research Information Service (2009). Infrastructures plan of digital text service environments for commercialization: RM 2009-15, 2009 issue report.

25. Rosić, M., Glavinić, V., \& Stankov, S. (2006). Intelligent tutoring interoperability for the new web. Telecommunications Systems, 32, 193-207.

26. Shepperd, J. A., Grace, J. L., \& Koch, E. J. (2008). Evaluating the electronic textbook: is it time to dispense with the paper text? Teaching of Psychology, 35(1), 2-5.

27. Son, B. G., Seo, Y. K., \& Byun, H. S. (2004). A case study of Korean and foreign digital textbooks. Korea Education \& Research Information Service.

28. Song, J., Song, J., Byun, G., Kim, S. J., \& Lee, B. G. (2009). Appropriate network systems for using digital textbook in u-learning environment. In ICUT international conference on ubiquitous information technology \& application 2009, Dec. 2009.

29. The bank of Korea (2010). Economic statistics system. http:// ecos.bok.or.kr/.

30. Vernon, R. F. (2006). Paper or pixels? An inquiry into how students adapt to online textbooks. Journal of Social Work Education, 42(2), 417-427.

31. Yang, X., Zhu, J., Guo, X., \& Wang, T. (2010). Intermittent WLAN and interactions across heterogeneous wireless networks. Telecommunications Systems, 43, 13-24.

32. Zeadally, S., Zomaya, A., \& Chao, H.-C. (2009). Editorial for special issue of telecommunication systems on "mobility management and wireless access". Telecommunications Systems, 42, $163-164$

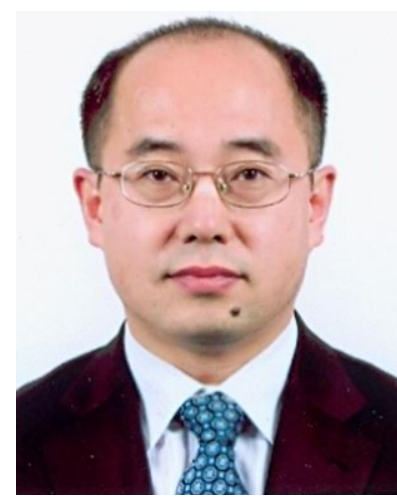

Jae Sung Song received his B.A. and M.A. degree in economics from Seoul National University, South Korea in 1989 and 1993, respectively. He is currently a Ph.D. Candidate in information systems at Yonsei University, South Korea. His research interests include competition policy in communication industry, mobile WiMax and digital textbook.

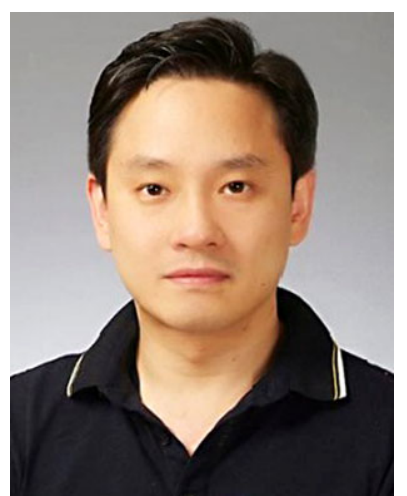

Seong Jin Kim received his M.S. Degree from Korea Advanced Institute of Science and Technology in 2004 and his Ph.D. from Yonsei University in 2010.

He now holds the position of deputy director at National IT Industry Promotion Agency. He has strived to apply the open-source to the Korean digital-text book system. His research interests include the measuring of the quality and effectiveness of u-learning services and customer satisfaction. 


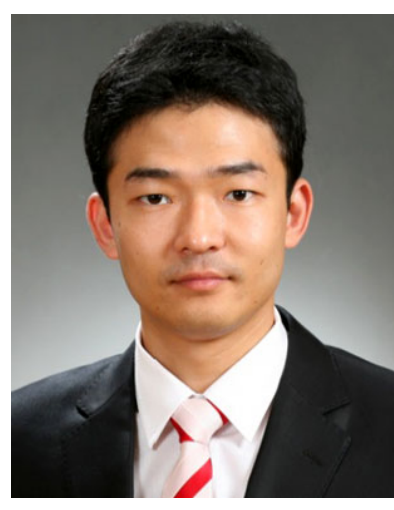

Gi Seob Byun received his B.E. degree in Department of Computer and Information Science at Korea University, South Korea in 2009. $\mathrm{He}$ received his M.A. in Information System from Graduate School of Information in the University of Yonsei, South Korea in 2011. His main research interests are IT Policy and Industry for government and enterprise, such as Green ICT, Policy for Convergence Broadcasting $\&$ Telecommunications and Digitaltext book system.

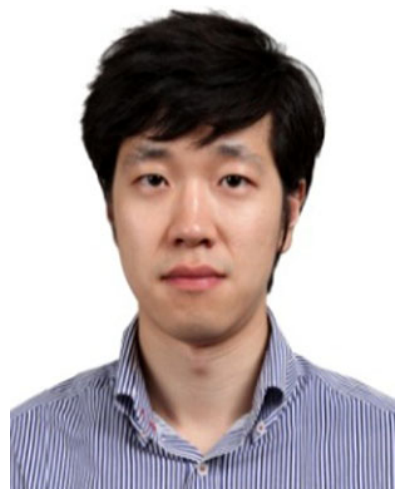

Ju Ho Song received his B.E. degree in Information System Engineering from the University of Hansung, Seoul, South Korea, in 2008. $\mathrm{He}$ received his M.A. in Information System from Graduate School of Information in the University of Yonsei, Seoul, South Korea in 2011 $\mathrm{Feb}$. He is currently a researcher in Communications Policy Research Center, Seoul, South Korea. His research interests include convergence of ICT and other industries, Government 2.0 and IT policy, as well as service quality evaluation.

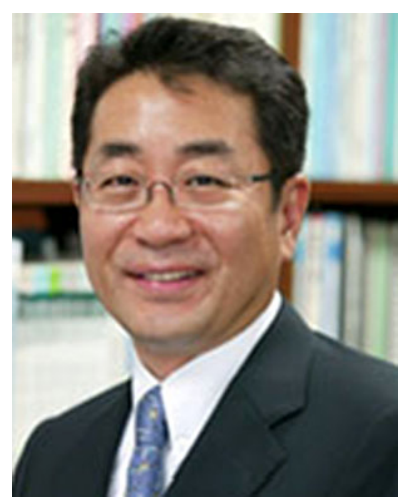

Bong Gyou Lee is an Associate Dean and Professor at the Graduate School of Information in Yonsei University. He received his B.A. degree from Yonsei in 1988 and his M.S. degree in 1992 and Ph.D. in 1994 from Cornell University. He is currently chief editor of the Korea Information Processing Society Review. 